\title{
POSKUS VEČKRITERIJSKEGA ISKANJA ALTERNATIVNIH KRMNIH RASTLIN NA OBMOČJU SPODNJE SAVINJSKE DOLINE
}

\author{
Alenka Jelen, dipl. geogr. in šp. jez. in knjiž.*, dr. Blaž Repe** \\ * Pondor 13, SI-3304 Tabor \\ ** Oddelek za geografijo, Filozofska fakulteta Univerze v Ljubljani \\ Aškerčeva 2, SI-I000 Ljubljana \\ e-mail: aknela.jelen@gmail.com, blaz.repe@ff.uni-lj.si
}

\section{Pregledni znanstveni članek}

COBISS 1.02

DOI: 10.4312/dela.43.6.89-107

\section{Izvleček}

Od 19. st. dalje se $\mathrm{z}$ intenzifikacijo živinoreje in vse večjih potreb po mesnih izdelkih za krmo živine uporabljajo predvsem rastline $\mathrm{z}$ velikim hektarskim donosom in hranljivostjo. Med njimi prevladuje silažna koruza, ki je zelo ranljiva za pomanjkanje vode ter vročinske valove, če se ti pojavijo v ključnih fenofazah. V članku z vidika kriterija rastlinske odpornosti na sušo in ekonomike pridelovanja iščemo možnosti uporabe drugih krmnih rastlin, predvsem krmnih žit in metuljnic, kot alternativo silažni koruzi.

Ključne besede: silažna koruza, krmne rastline, NDVI, kmetijska suša, geografija naravnih nesreč, Spodnja Savinjska dolina

\section{MULTI-CRITERIA EVALUATION OF THE ALTERNATIVE FODDER CROPS USE IN THE LOWER SAVINJA VALLEY}

\begin{abstract}
From the 19th century onwards, with the intensification of livestock production the demand for meat products is increasing. For animal feed are primarily used plants that allow maximum yield per hectare. Among them, the dominant crop is silage maize but, it is very vulnerable crop due to water shortages and heat waves during the peak growing season. In this article, we are looking for opportunities to use other fodder crops as alternative to silage maize, especially cereals and fodder legumes.
\end{abstract}

Key words: silage maize, fodder crops, NDVI, agricultural drought, natural hazards, Lower Savinja Valley 


\section{UVOD}

V zadnjem času se bolj zavedamo, da je človek povsem nemočen pred naravnimi pojavi, kot so poplave, suše in druge vremenske ujme ter plazovi. Teh pojavov sicer ni nič več, kot jih je bilo v preteklosti, a so časovno drugače razporejeni prek leta. Obenem je človek zaradi netrajnostnega in nesonaravnega načina bivanja, delovanja in pridelovanja vse bolj ranljiv. Poleg tega smo zaradi boljše medijske pokritosti tudi bolje informirani o dogodkih. Pogosti načini soočanja z naravnimi pojavi so predvsem osredotočeni na odpravljanje posledic pojavov. Še vedno se posveča premalo pozornosti preventivnim, trajnostnim ukrepom, ki bi lahko z interdisciplinarnimi pristopi dodobra omilili posledice ali jih celo preprečili. Državne ustanove bi morale pripraviti ustrezno strategijo za preprečevanje in zmanjševanje posledic naravnih nesreč (Krepitev pripravljenosti Evrope ..., 2013; Adaptation strategies, 2014).

$\mathrm{V}$ prispevku se bomo osredotočili na sušo in ukrepe za zmanjšanje oziroma preprečevanje njenih posledic. Med takšne ukrepe sodi nadomeščanje rastlin, ki so na sušo zelo slabo prilagojene s tistimi, ki so bolje prilagojene in kljub temu še vedno dajejo ekonomsko upravičen hektarski donos. Ukrep je po ocenah nekaterih agrometeorologov razmeroma uspešen način spopadanja s sušo (Grah, 2012), čeprav se v kmetijski praksi pogosteje odločajo za katerega izmed drugih ukrepov za zmanjšanje škode zaradi suše. Mednje sodijo namakanje, gnojenje, pridelovanje hibridnih sort koruze, uporaba fitofarmacevtskih sredstev, zgodnejše pobiranje pridelkov itd. Ne glede na to je ukrep nadomestnih rastlin mogoče zaslediti v literaturi, celo v tehnoloških priporočilih za zmanjšanje občutljivosti kmetijske pridelave na sušo (Tehnološka priporočila za ..., 2008). Kot nadomestne rastline se najpogosteje priporoča različne zrnate krmne rastline (pšenica, oves, proso, ječmen, soja, krmni bob, krmni grah itd.) ter metuljnice (lucerna, inkarnatka, različne vrste detelj in že zgoraj omenjene stročnice - soja, bob, grah itd.). Nekatere od teh, predvsem zrnate krmne rastline, so bile v preteklosti zelo cenjene in tudi bolj uveljavljene za krmo živine, saj vsebujejo precej visoke koncentracije škroba. Njihovo pridelovanje se je kasneje zmanjšalo, saj je koruza zagotavljala količinsko večje pridelke z mnogo višjo škrobno vrednostjo (Korošec, 1989). Predvideva se tudi, da je na uveljavitev koruze v živinoreji močno vplival prihod železnice v drugi polovici 19. st., ki je prinesel večjo liberalizacijo trga ter znižanje cen mleka (Bernik, 1998). Kmetijstvo je bilo primorano stremeti k vse bolj intenzivni pridelavi, saj so bile v živinoreji potrebne večje količine krme.

Pri iskanju nadomestnih rastlin je potrebno upoštevati več različnih dejavnikov. Prvi pogoj so rastne zahteve rastline, kot so prst, potrebe po vodi, podnebje, relief itd. Poleg teh na izbiro vplivajo tudi pridelovalni stroški ter hektarski donos. To kaže na potrebo po natančnem prikazu primernih vrst nadomestnih rastlin, z vsemi potrebnimi parametri, kar bi pridelovalcem omogočilo lažjo odločitev (Korošec, 1989).

$\mathrm{V}$ raziskavi smo se ukvarjali s silažno koruzo in nekaterimi drugimi krmnimi rastlinami. Ugotavljali smo njihovo prilagodljivost na sušo z metodo daljinskega zaznavanja - vegetacijskega indeksa NDVI (ang. Normalized Difference Vegetation Index) in ekonomiko pridelovanja krmnih rastlin ter izpostavili najprimernejše rastline, ki bi lahko nadomestile silažno koruzo. Obravnavane krmne rastline smo izbrali na podlagi literature 
in bi lahko bile po priporočilih agronomov dovolj dobro nadomestilo silažni koruzi (npr. nekatere metuljnice in krmna žita). Kot dodatni razlog lahko navedemo, da so jih v različnih rastnih pogojih več let testirali na poskusnih poljih. V okviru te raziskave nismo izvajali dodatnih testiranj, s katerimi bi preučevali možnosti zamenjave silažne koruze z drugimi kulturnimi rastlinami.

\section{I.I Obravnavano območje}

V prvem delu analize smo se osredotočili na območje šestih občin Spodnje Savinjske doline (Braslovče, Polzela, Prebold, Tabor, Vransko in Žalec). Območje je zaradi ugodnih naravnih pogojev (večje sklenjeno ravninsko območje, za kmetijstvo zelo primerne prsti, zadostne povprečne letne količine padavin itd.) še vedno pretežno kmetijsko. Zato je tudi delež delovno aktivnih prebivalcev v primarni dejavnosti visok $(18,9 \%) \mathrm{v}$ primerjavi s slovenskim povprečjem $(4,9 \%$; 2010). Še posebej izstopa občina Tabor s 30,9 \% zaposlenih v primarni dejavnosti (Družinski člani na ..., 2015).

Po podatkih popisa kmetijstva leta 2010 po namenu kmetijske pridelave prevladujejo kmetijska gospodarstva s pridelavo za (izključno ali pretežno) lastno porabo (787 kmetijskih gospodarstev; 53 \%). Delež tržno usmerjene pridelave je v Spodnji Savinjski dolini (47 \%) nad slovenskim povprečjem (40,5 \% kmetijskih gospodarstev; 2010), kljub obdobno neugodnim gospodarskim razmeram v hmeljarstvu. Prevladuje specializirana pašna živinoreja, pogoste oblike so še mešane kmetijske dejavnosti poljedelstva in živinoreje ter mešane živinoreje in poljedelstva (Kmetijska gospodarstva po rabi ..., 2013).

Slika 1: Poljščine po deležih površin v občinah Spodnje Savinjske doline v letu 2010 Figure 1: Main crops by shares of agricultural land in the municipalities of the Lower Savinja Valley (percentage of area)

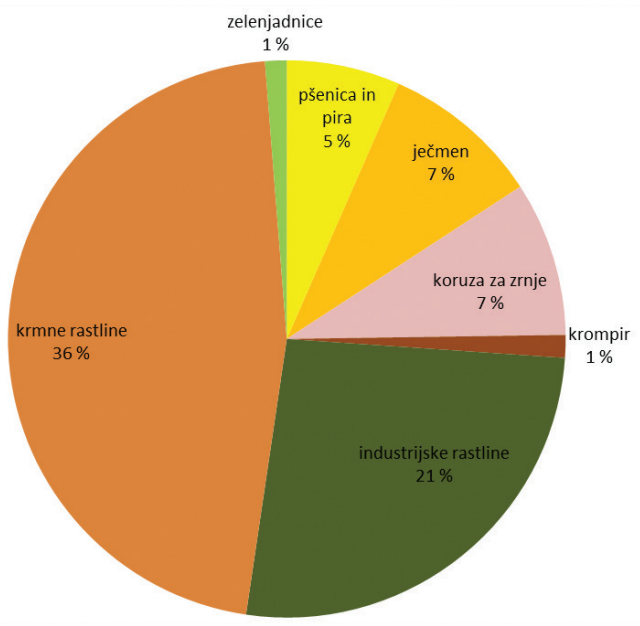

Vir/Source: Kmetijska gospodarstva po rabi ..., 2013 
Med vrstami poljščin prevladujejo krmne rastline (silažna koruza, metuljnice) s $36 \%$, sledijo industrijske rastline z $21 \%$ in žita z $19 \%$ vseh kmetijskih površin v Spodnji Savinjski dolini (slika 1). Med poljščinami prevladuje silažna koruza (1305 ha; 60,6 \%), kar celo presega pridelavo hmelja (1218 ha). Med žiti prevladujeta ječmen (428 ha) in koruza za zrnje (416 ha), ki se prav tako uporabljata za krmo živali (Kmetijska gospodarstva po rabi ..., 2013).

$\mathrm{V}$ drugem delu analize smo zaradi narave raziskave obravnavali celotno Slovenijo. Upoštevali smo hektarski donos ter odkupno ceno silažne koruze in krmnih rastlin v sušnem letu 2012.

\section{I.2 Rastne značilnosti koruze}

Koruza (Zea mays L.) je kritosemenka in enokaličnica. Po prilagodljivosti na svetlobo jo uvrščamo med $\mathrm{C} 4$ rastline, to je rastline, ki so se prilagodile na vroče in sušno okolje z veliko količino svetlobe. V procesu fotosinteze lahko vgrajujejo $\mathrm{CO}_{2}$ pri zelo močni svetlobi ali ob višji temperaturi. Koruza najbolje uspeva na prsteh s srednje težko teksturo, ki imajo ugoden delež humusa. To so prsti peščeno-glinaste in peščeno-ilovnate teksture z deležem humusa od 2 do $4 \%$. Koruza razvije plitev šopast koreninski sistem, ki sega do maksimalne globine $30 \mathrm{~cm}$. Njeno absorbcijsko območje je majhno, primerljivo krogu s premerom $45 \mathrm{~cm}$. Za pridelovanje koruze je potrebna povprečna mesečna temperatura $\mathrm{V}$ rastni dobi od maja do konca septembra vsaj $13,5^{\circ} \mathrm{C}$. Setev poteka v globino med 3 in $6 \mathrm{~cm}$, ko se temperatura tal na globini $5 \mathrm{~cm}$ zviša na $8{ }^{\circ} \mathrm{C}$, oziroma pri semenu z nižjo biološko vrednostjo med 10 in $12^{\circ} \mathrm{C}$. Setev se običajno prične že konec aprila, vendar je to zelo različno, odvisno od vrste dejavnikov, predvsem od vremenskih razmer, a tudi od vrste in sorte koruze (Čergan, 2008).

$\mathrm{V}$ celotni rastni dobi koruza na vsakem kvadratnem metru površine za rast in razvoj neposredno porabi približno 7001 vode. Obenem so v vročem in sušnem okolju še velike izgube vode zaradi evapotranspiracije. Poraba vode narašča s temperaturo in $\mathrm{z}$ nižanjem zračne vlažnosti. Razlike v porabi vode so opazne tudi v različnih razvojnih fazah. Najvišja poraba je v času cvetenja (metličenje in svilanje) in oploditve (slika 2), ki potekata med 10. julijem in 10. avgustom, lahko tudi več kot 20 dni. Koruza je prav v tem času najbolj občutljiva za pomanjkanje vode. Posledice se kažejo v zmanjšanju pridelka (slika 3) in v različnih poškodbah, npr. zmanjšanju višine rastline, zakrnelosti storžev, slabši oploditvi, sušenju listov, zmanjšani odpornosti proti škodljivcem in boleznim (Čergan, 2008).

Koruza se na sušo odziva mnogo slabše kot nekatere druge rastline. Pri njej namreč čas cvetenja in oploditve $\mathrm{v}$ zmernem pasu pogosto sovpada $\mathrm{z}$ najvišjimi temperaturami in primanjkljajem padavin. Kljub temu nekateri ugotavljajo, da je koruza, poškodovana zaradi suše, še bolj hranljiva kot v običajnih razmerah. Zaradi pomanjkanja vode v prsti se škrob namesto v zrnju kopiči v steblu (Prepadnik, 2012). Kljub temu je pridelek količinsko manjši, pogosto ga uničijo še različni škodljivci in tako ni uporaben za krmo živali (Čergan, 2008). 
Slika 2: Dnevne količine padavin, potrebne za rast koruze v posamezni fenološki fazi Figure 2: The daily rainfall requirements of maize by phenophases

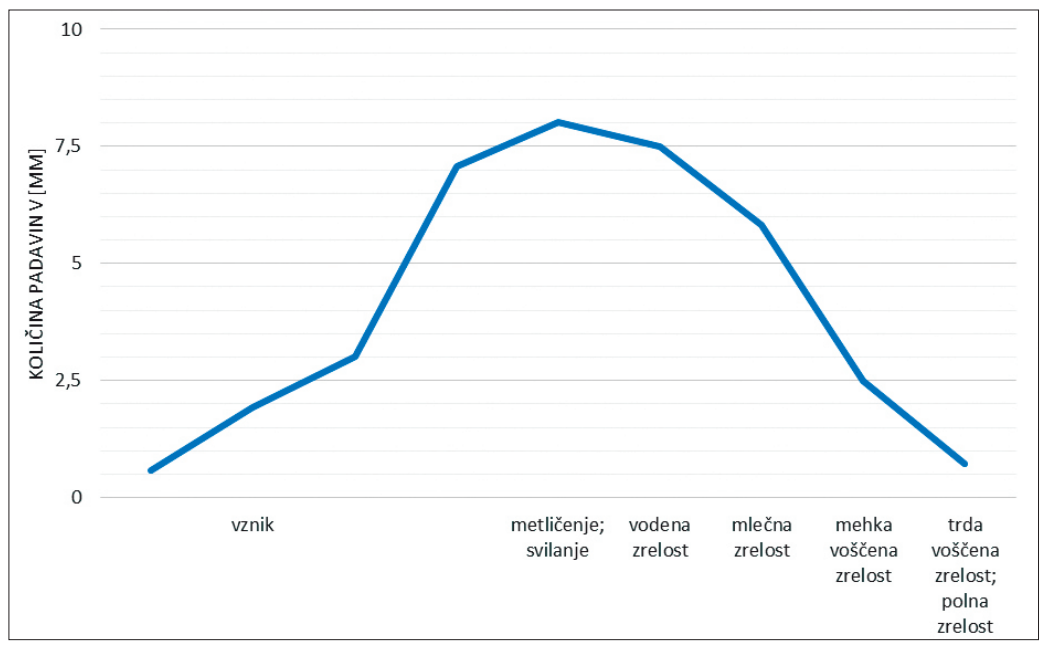

Vir/Source: Čergan, 2008

Slika 3: Zmanjšanje pridelka koruze zaradi pomanjkanja vode v posameznih fenofazah Figure 3: Maize yield reduction due to the lack of water by phenophases

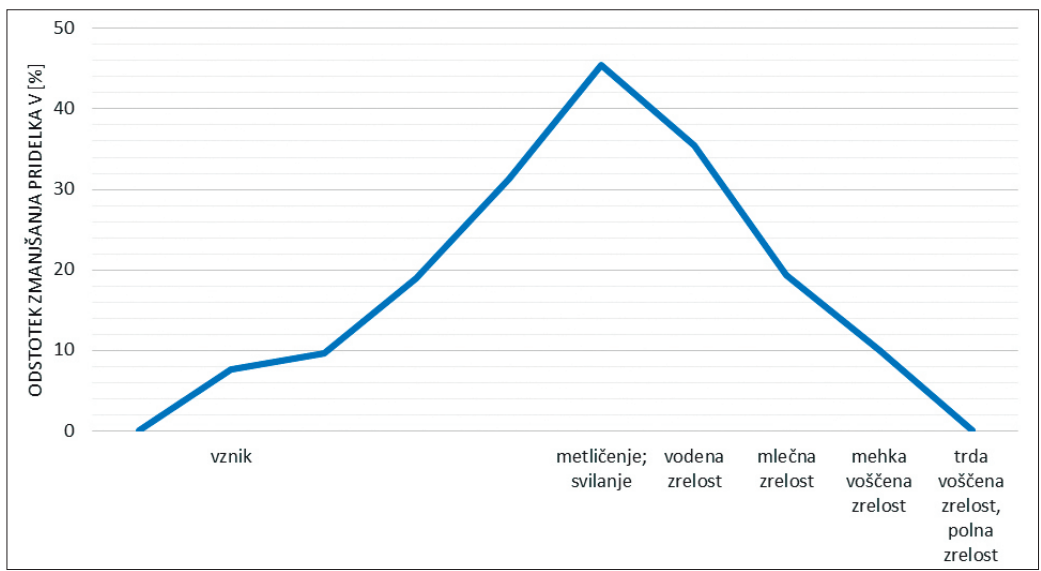

Vir/Source: Čergan, 2008 
Slika 4: Polje silažne koruze v Braslovčah v juliju 2013 (foto: A. Jelen)

Figure 4: The field of silage maize in Braslovče in July 2013 (photo: A. Jelen)

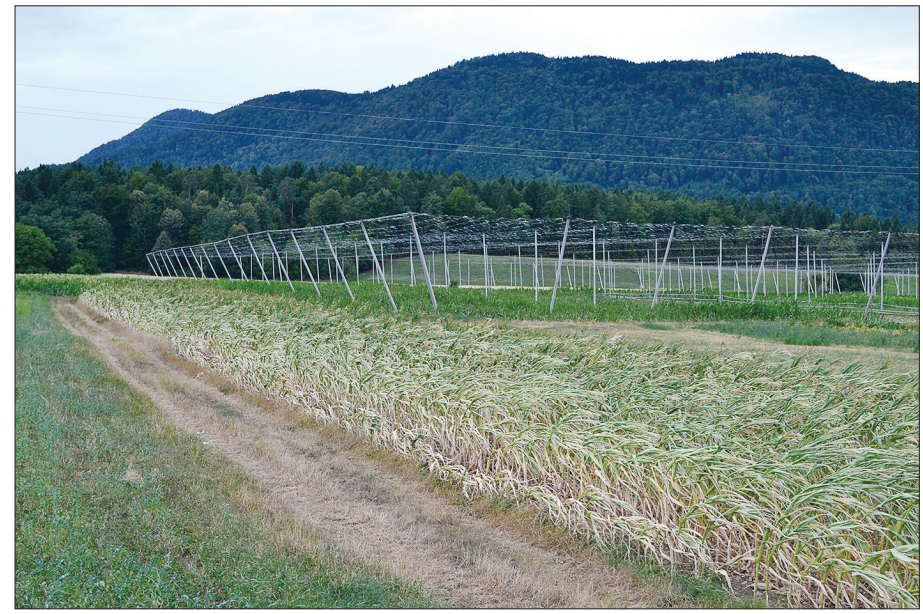

Slika 5: Močno poškodovano polje koruze v Pondorju v začetku avgusta 2013 (foto: A. Jelen) Figure 5: Heavily damaged maize field in Pondor in the early August 2013 (photo: A. Jelen)

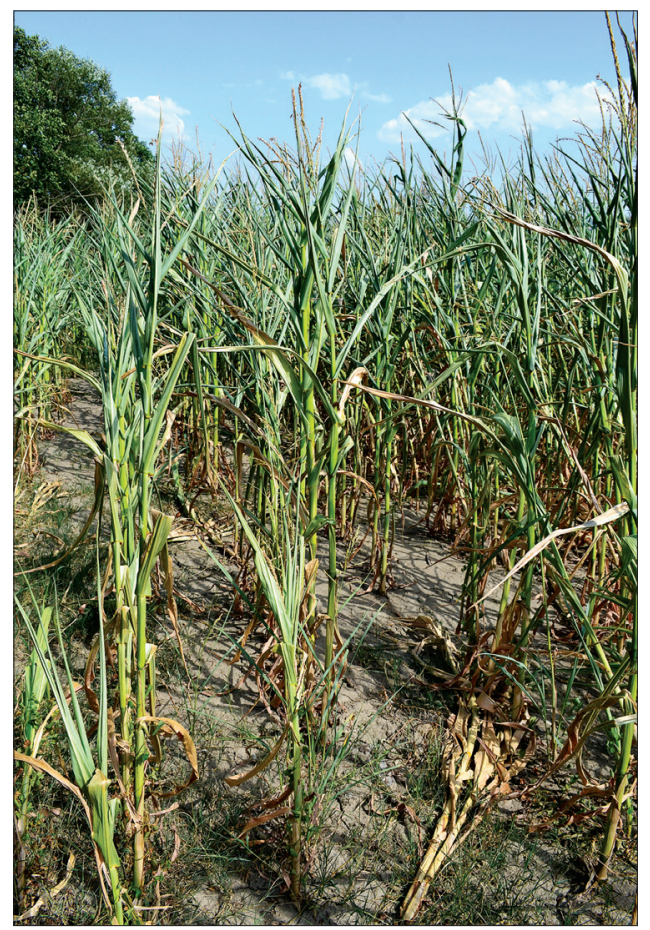




\section{METODOLOGIJA}

Primernost pridelave nadomestnih krmnih rastlin namesto silažne koruze smo določali z dvema kriterijema: rastno odpornostjo pred sušo ter ekonomiko pridelovanja silažne koruze in nadomestnih rastlin. S tem smo želeli določiti najprimernejšo nadomestno krmno rastlino in zadostiti različnim dejavnikom, ki vplivajo na odločitev kmetovalcev o pridelovanju krmnih rastlin.

\section{I Rastna odpornost rastlin pred kmetijsko sušo}

Rastna odpornost rastlin pred kmetijsko sušo je stopnja poškodovanosti posamezne rastlinske vrste $\mathrm{v}$ času višjih temperatur in primanjkljaja v vodni bilanci. Rastno odpornost smo določili z deležem poškodovanosti morfološke strukture rastlin. Pridobili smo ga $\mathrm{z}$ vegetacijskim indeksom NDVI ter ga dodatno preverili s podatki o ocenjeni škodi na kmetijskih kulturah zaradi kmetijske suše. NDVI izračunamo kot razmerje med razliko vrednosti bližnje infrardečega $(I R)$ in rdečega $(R)$ kanala ter njuno vsoto.

$$
N D V I=\frac{(I R-R)}{(I R+R)}
$$

Osnovno interpretacijo lahko opravimo vizualno, saj intenzivne zelene barve pomenijo zdravo rastje, manj intenzivne zelene do rjave in sive nezdravo rastje, pozidane površine brez rastja ali vodne površine. $V$ analizi smo izločili vodne in pozidane površine, saj imajo te podobne vrednosti kot poškodovano rastlinstvo. Vrednosti indeksa NDVI se nahajajo $v$ intervalu med -1 in +1 . Višja vrednost indeksa kaže na intenzivnejše rastje in s tem tudi bolj zdravo in manj poškodovano zaradi suše (Oštir, 2006). Vrednosti indeksa NDVI so se na preučevanem območju občin Spodnje Savinjske doline v juliju 2012 gibale med -1 in $+0,62$.

Pri analizi rastne odpornosti smo najprej določili prostorsko razširjenost izbranih kulturnih rastlin. Poleg silažne koruze smo vključili izbrane krmne rastline, ki so jih v letu 2012 kmetovalci prav tako pridelovali na preučevanem območju: deteljo, lucerno, deteljno-travne mešanice ter travno-deteljne mešanice. Podatke o vrstah poljščine na vsakem GERK-u (grafična enota rabe kmetijskih gospodarstev) za kategoriji rabe tal njiva in hmeljišče (šifri rabe tal 1100 in 1160) smo pridobili na Agenciji za kmetijske trge in razvoj podeželja (Podatki o vrsti ..., 2013). Ključna dejavnika za izbor teh krmnih rastlin sta bila dejanska pridelava na tem območju v preučevanem obdobju ter najmanjša pridelovalna površina (1 ha). Ker se po metodologiji vpisa v GERK upošteva le glavne vrste rastlin, podrobnejši izbor in analiza nista bila mogoča. Tako so vrste metuljnic, kot so inkarnatka, aleksandrijska detelja itd. uvrščene v kategorijo detelj. Podobno je tudi pri mešanicah, saj ne vemo natančno, katere rastline jih sestavljajo (Podatki o vrsti ..., 2013).

Sledil je izračun vegetacijskega indeksa NDVI na nivoju posamezne njive $\mathrm{z}$ določeno krmno rastlino. Za izračun vegetacijskega indeksa NDVI je potrebno izbrati satelitski 
posnetek iz ustreznega časovnega obdobja, ko je večina krmnih rastlin v najobčutljivejših fazah vegetacijskega obdobja. V tem obdobju so lahko poškodbe zaradi suše za nekatere vrste usodne in vplivajo na končni pridelek same rastline. Izbrali smo satelitski posnetek satelita Landsat 7 ETM+, posnet 9. julija 2012, z visoko kvaliteto posnetka (stopnja 9 od 10) in neznatno oblačnostjo (6 \%) (NASA Landsat Program ..., 2013). Omenjeni satelit je od 31. 6. 2003 v okvari, saj se je pokvaril korektor snemalnih vrstic. Na posnetku se tako pojavljajo diagonalne vrstice, ki zajemajo približno $22 \%$ podatkov celotnega posnetka. Napake smo odpravili s programom Landsat Gapfill, ki zapolnjuje vrzeli z metodo triangulacije z upoštevanjem mejnih vrednosti (Stevenson, 2012). Sicer je bolje, da posnetkov s takšnimi ali podobnimi napakami za potrebe znanstvenih analiz ne uporabljamo. V našem primeru zaradi objektivnih razlogov (preučevano obdobje poletje 2012, nedelovanje drugih satelitov v tem obdobju) tega ni bilo mogoče zaobiti. Izračun NDVI smo izvedli z orodjem VegIndex v programu IDRISI Taiga.

Poleg indeksa NDVI smo rastno odpornost določili še s stopnjo poškodovanosti rastlin zaradi kmetijske suše ter rezultate obeh primerjali med seboj. Uporabili smo podatke o ocenjeni stopnji škode za leto 2012 na kmetijskih zemljiščih, pridobljenih na Upravi RS za zaščito in reševanje. Kazalnik prikazuje delež površin poškodovanih poljščin zaradi suše glede na celotno površino zemljišča. Površina poškodovanega posevka je morala biti vsaj 31 \% (Ocena škode na ..., 2013), da se je poljščina lahko uvrstila med poškodovane zaradi suše. Podatke o stopnji poškodovanosti smo prikazali in analizirali tudi prostorsko tako, da smo jih združili s prostorskim prikazom GERK za leto 2012.

\subsection{Ekonomika pridelovanja krmnih rastlin}

Kmetovalci, ki se poleg živinoreje ukvarjajo tudi s pridelavo krme, se pogosto srečujejo z ekonomiko pridelovanja rastlin. Pri tem je bistvenih več dejavnikov, mdr. zadostna količina potrebnih hranil, hektarski donos in nizki stroški pridelave. V naši raziskavi smo te kriterije uporabili pri iskanju ustrezne nadomestne rastline. Ekonomiko pridelovanja krmnih rastlin smo določili z več kazalniki: potrebe krave molznice po škrobu in beljakovinah, odkupna cena pridelka, pridelanega na hektarju površine, ter stroški pridelave krmne rastline.

S prvim kazalnikom podajamo dnevno in letno potrebo krave molznice po škrobu in beljakovinah za vzdrževanje telesne mase (vzdrževalna funkcija) in proizvodnjo mleka (proizvodna funkcija). Izračunali smo ga ob naslednjih predpostavkah: upoštevali smo povprečno telesno maso $(600 \mathrm{~kg})$ krave molznice črnobele pasme, ki ni breja in ne potrebuje dodatnih hranil za vzrejo prirasta ter daje povprečno dnevno 20 litrov mleka (Korošec, 1989) s povprečno laktacijo 305 dni (Podgoršek, Perpar, 2012). Upoštevali smo povprečno vsebnost maščob v mleku (4 \%). Višja kot je vsebnost maščob v mleku, večje so potrebe po škrobu in beljakovinah (Korošec, 1989).

Potrebe živali po hranilnih snoveh smo podali s škrobnimi enotami (ŠE) in prebavljivimi beljakovinami (PB). Škrobna enota (ŠE) je vrednost, učinkovitost posameznega hranila v primerjavi s čistim škrobom (škrobna moka) in predstavlja delež škroba V krmi. En kg koruze predstavlja 800 ŠE, ima torej enak učinek kot 800 g škrobne moke. 
Prebavljive beljakovine (PB) se določajo na podlagi beljakovinskega razmerja, $\mathrm{tj}$. razmerja med prebavljivimi beljakovinami (PB) in škrobnimi enotami (ŠE). Pri proizvodnji mleka je to razmerje $1: 4,6$, pri vzdrževalni funkciji pa $1: 10$. Krave molznice črnobele pasme tako za proizvodnjo mleka potrebujejo $275 \mathrm{~g}$ ŠE ter $60 \mathrm{~g}$ PB na liter mleka dnevno. Za vzdrževanje telesne mase dnevno potrebujejo 3200 g ŠE ter 320 g PB (Cizej, 1991). Po izračunu dnevnih in letnih potreb po škrobu in beljakovinah za vzdrževanje telesne mase in proizvodnjo mleka smo izračunali še količino povprečne dnevne količine različnih vrst krme, s katero bi pokrili potrebe krave molznice po hranilih. Upoštevali smo obstoječe podatke ŠE in PB na $1 \mathrm{~kg}$ krme v povprečnem enkratnem (ena košnja oz. ena žetev) hektarskem donosu krmne rastline (Korošec, 1989).

Naslednja kazalnika ekonomike pridelovanja krmnih rastlin sta odkupna cena pridelka, pridelanega na hektarju površine, ter stroški pridelave. Hektarski donos je kazalnik, ki nam podaja donosnost, količino določenega pridelka na enem hektarju kmetijske površine. Za pridelovalce je to pomemben podatek, saj se tudi na podlagi tega odločijo za pridelovanje določene kulturne rastline (Korošec, 1989). Uporabili smo podatke o količinah rastlinske pridelave v letu 2012 (Krznar, 2013) ter indekse cen kmetijskih pridelkov pri pridelovalcih za leto 2012 Statističnega urada Republike Slovenije (Indeksi cen in cene ..., 2013). Ker se za nekatere krmne rastline ne zbirajo podatki o cenah, smo pregledali oglase kmetovalcev na različnih spletnih straneh (kmetijskioglasnik.si; bolha.com itd.) za preučevano časovno obdobje in se posvetovali s kmetovalci in agronomi ter upoštevali srednje vrednosti cen. Izračunane odkupne cene pridelka na hektarju površine smo nato primerjali še z izračuni stroškov pridelave poljščin. Takšna primerjava namreč omogoča, da preverimo, ali imajo kmetovalci ob pridelovanju krme dobiček ali le pokrivajo večino stroškov. Izračune stroškov pridelave poljščin smo povzeli po modelnem izračunu Kmetijskega inštituta Slovenije za leto 2012. Izračun obsega stroške materiala, najetih storitev, stroške dela in drugih obveznih dajatev. Od izračunanih stroškov so že odštete pridobljene subvencije (Kalkulacije v rastlinski ..., 2013).

\section{RAZPRAVA}

\section{I Rastlinska odpornost}

Preglednica 1 prikazuje rezultate izračunov NDVI. Območje preučevanja smo razdelili na dve različni reliefni območji. V ravninskem delu do $300 \mathrm{~m} \mathrm{n}$. v. je bila poškodovanost vseh rastlin višja kot v gričevnatem in hribovitem območju nad $300 \mathrm{~m} \mathrm{n}$. v. Razlogi za razlike so verjetno $\mathrm{v}$ rastnih pogojih, tipih prsti, reliefu in vegetaciji. V gričevnatem in hribovitem pasu prevladujejo gozdne površine, ki delujejo kot naravni zadrževalnik presežkov padavin. Poleg tega gozdne površine s prestrezanjem padavin skladiščijo vodo, kar bližnjim poljščinam nudi dodaten vir vode ob sušah, in tudi zmanjšujejo evapotranspiracijo (Brilly, Šraj, 2005).

Slika 6 prikazuje izračunan NDVI za celotno območje preučevanja, tudi za površine, ki jih v okviru raziskave nismo analizirali (gozd, pozidane in vodne površine). Različne 
vrste površin smo razdelili v kategorije poškodovanosti. Pozidane in vodne površine smo izločili s prekrivanjem več slojev (kataster stavb, ceste, kategorizirani vodotoki, vodne in druge pozidane površine) in ugotovili, da zavzemajo območja z NDVI pod $-0,55$. Ostale površine so predstavljale različno poškodovano rastlinstvo, ki smo jih uvrstili v posamezne stopnje poškodovanosti z naravnim intervalom po Jenksu. V času snemanja satelitskega posnetka, v začetku julija 2012, so bile nekatere poljščine v ključnih fenofazah in zato bolj ranljive za vremenske razmere. To se kaže tudi v vrednostih NDVI, ki so zato nizke ali celo negativne. Bolj ranljivo je ravninsko območje, kjer je človek s poselitvijo krčil gozdne in vodne površine ter ustvaril umetne kmetijske ekosisteme, potrebne nenehnega vzdrževanja.

$\mathrm{Na}$ ravnini sta bili najmanj poškodovani lucerna in detelja, podobne vrednosti dosegata tudi obe travni mešanici (preglednica 1). Najbolj je bila poškodovana silažna koruza. $\mathrm{V}$ podobnem razmerju, a $\mathrm{z}$ nižjo stopnjo poškodovanosti, so bile vrednosti tudi v gričevnatem in hribovitem območju.

Preglednica 1: Povprečne vrednosti NDVI za izbrane krmne rastline Table 1: The average NDVI values for the selected fodder crops

\begin{tabular}{|l|c|c|c|}
\hline Krmna rastlina & $\begin{array}{c}\text { NDVI celotnega } \\
\text { območja }\end{array}$ & $\begin{array}{c}\text { NDVI na ravninskem } \\
\text { območju (do 300 } \mathbf{~ m} \\
\text { n. v.) }\end{array}$ & $\begin{array}{c}\text { NDVI v gričevnatem } \\
\text { in hribovitem območju } \\
\text { (nad 300 m n. v.) }\end{array}$ \\
\hline Silažna koruza & 0,17 & 0,13 & 0,18 \\
\hline Detelja & 0,21 & 0,20 & 0,23 \\
\hline Lucerna & 0,22 & 0,21 & 0,25 \\
\hline Deteljno-travne mešanice* & 0,18 & 0,18 & 0,22 \\
\hline Travno-deteljne mešanice** & 0,20 & 0,18 & 0,19 \\
\hline
\end{tabular}

* Deteljno-travne mešanice so mešanice trav, kjer prevladujejo detelje. Primerne so le za kratkotrajno pridelovanje na njivah.

** Travno-deteljne mešanice so mešanice, kjer je delež trav v mešanici višji od deleža detelj. Namenjene so setvi večletnih in trajnih travnikov (Korošec, 1989).

Na preučevanem območju je bila s popisom določena škoda zaradi suše na 32,8 \% vseh kmetijskih zemljišč, večinoma v ravninskem območju (približno do n. v. 300 m). Po podatkih Uprave RS za zaščito in reševanje je celotna škoda v letu 2012 na območju preučevanih občin znašala 10.371.388 € (Ocena škode na ..., 2013). Naši izračuni kažejo, da je bilo največ škode v hmeljarstvu in pridelavi silažne koruze. Po površini je bilo največ poškodovanih trajnih travnikov (2493 ha), čeprav je bila stopnja poškodovanosti teh razmeroma nizka (35\%). 
Slika 6: Poškodovanost kmetijskih in drugih površin glede na vrednosti NDVI

Figure 6: The damage of agricultural and other areas according to the NDVI values

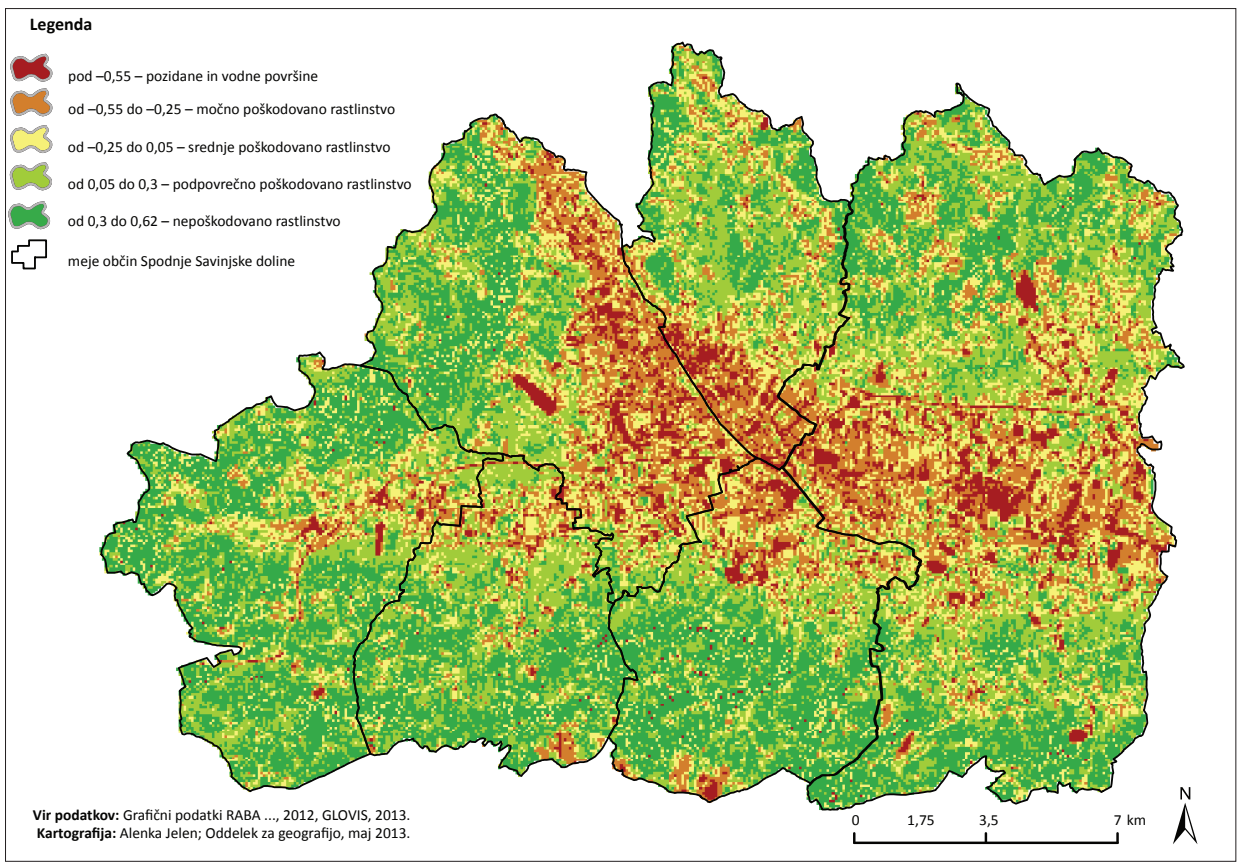

Na sliki 7 so prikazani vsi GERK-i kmetijskih površin. Razvrščeni so v več kategorij glede na povprečno stopnjo poškodovanosti. V zahodnem delu območja prevladujejo nepoškodovane površine, saj so na Vranskem ocenili, da ni bilo škode zaradi suše. V vzhodnem delu prevladujejo povprečno poškodovane površine, medtem ko na prodnatem vršaju Savinje v osrednjem delu območja prevladujejo nadpovprečno in katastrofalno poškodovane kmetijske površine, ki večinoma predstavljajo njivske površine.

Na celotnem območju je bilo zaradi suše poškodovanih 64 \% vseh površin (1015,6 ha), ki so bile posajene s koruzo (za zrnje in silažo). V ravninskem območju je bila povprečna poškodovanost koruze višja $(57,7$ \%) kot v pasu gričevij in hribovij $(54,7$ \%) (preglednica 2). Ostale obravnavane poljščine niso presegle $50 \%$-ne maksimalne stopnje poškodovanosti zaradi suše. Najnižja povprečna stopnja poškodovanosti celotnega območja je bila pri lucerni, sledita ji mešanici in detelja. Nekoliko nenavadni so bili rezultati za obe reliefni območji, saj je bila poškodovanost pri vseh metuljnicah in mešanicah višja na območju gričevij in hribovij. Tu je bila tudi večina površin metuljnic in mešanic, $\mathrm{v}$ ravninskem delu tovrstne pridelovalne površine niso zadostovale kriteriju 1 ha, zato jih je tam manj. Posledično je bilo manj poškodovanih površin v ravninskem delu kot na območju gričevij in hribovij. V nadaljnjih raziskavah bi bilo očitno potrebno dopolniti metodologijo in razširiti preučevano območje. 
Preglednica 2: Stopnja poškodovanosti krmnih rastlin zaradi suše po deležih površine Table 2: The stage of damage to fodder crops due to the drought (percentage of area)

\begin{tabular}{|l|c|c|c|}
\hline Krmna rastlina & $\begin{array}{c}\text { Povpr. stopnja } \\
\text { poškodovanosti na } \\
\text { celotnem območju }\end{array}$ & $\begin{array}{c}\text { Povpr. stopnja } \\
\text { poškodovanosti na } \\
\text { ravninskem območju } \\
\text { (do 300 } \text { m n. v.) }\end{array}$ & $\begin{array}{c}\text { Povpr. stopnja } \\
\text { poškodovanosti } \\
\text { v gričevnatem in } \\
\text { hribovitem območju } \\
\text { (nad 300 m n. v.) }\end{array}$ \\
\hline Silažna koruza & 57,0 & 57,7 & 54,7 \\
\hline Detelja & 47,8 & 39,2 & 48,0 \\
\hline Lucerna & 40,0 & 39,8 & 41,0 \\
\hline Deteljno-travne mešanice & 46,6 & 46,4 & 48,5 \\
\hline Travno-deteljne mešanice & 45,0 & 44,5 & 47,5 \\
\hline
\end{tabular}

Slika 7: Stopnja poškodovanosti rastlin glede na popis škode

Figure 7: The degree of plant damage according to the census

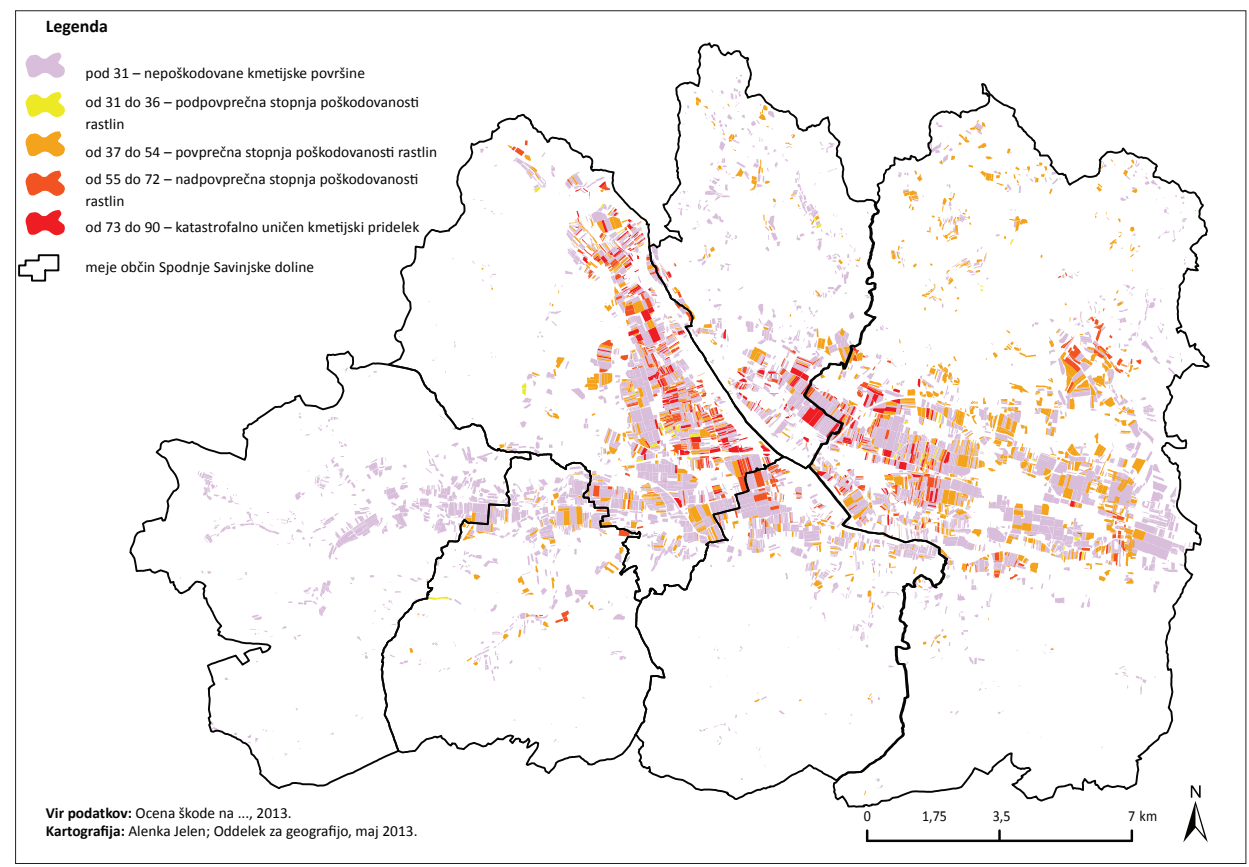

Iz izračunov NDVI in stopnje poškodovanosti rastlin po suši sledi, da je lucerna najprimernejša krmna rastlina kot nadomestek silažni koruzi. Tako pri analizi podatkov popisa škode zaradi suše kot pri NDVI je dosegla nižje vrednosti in bila manj poškodovana kot silažna koruza. Tudi ostale krmne rastline dosegajo vrednosti, ki kažejo, da so bile 
ob suši manj poškodovane in so torej odpornejše od silažne koruze. Pri analizi vrednosti NDVI in ocen popisa škode zaradi suše na obravnavanem območju ugotavljamo, da bi bilo pri nadaljnjih analizah potrebno obravnavati večje območje. Na tak način bi dobili različen nabor krmnih rastlin, kar bi dalo tudi natančnejše rezultate o njihovi odpornosti na ekstremne sušne in vročinske razmere.

\subsection{Ekonomika pridelovanja krmnih rastlin}

V preglednici 3 je prikazan primer izračuna potreb po škrobu in beljakovinah krave molznice črnobele pasme s $600 \mathrm{~kg}$ telesne mase, ki daje povprečno 20 litrov mleka dnevno s povprečno letno laktacijo 305 dni (Korošec, 1989; Podgoršek, Perpar, 2012). Ločeno so izračunane dnevne in letne potrebe po škrobu in beljakovinah za pridelavo mleka in vzdrževanje telesne mase ter njihova skupna količina.

Preglednica 3: Dnevne in letne potrebe krave molznice po škrobu in beljakovinah v krmi Table 3: Dairy cows daily and annual needs for starch and proteins

\begin{tabular}{|l|l|c|c|c|l|l|c|}
\hline $\begin{array}{l}\text { Krava } \\
\text { molznica } \\
\text { S 600 kg } \\
\text { telesne mase }\end{array}$ & $\begin{array}{l}\text { Povprečna } \\
\text { dnevna/ } \\
\text { letna } \\
\text { količina } \\
\text { mleka (l) }\end{array}$ & $\begin{array}{l}\text { Srkrob za } \\
\text { proizvajanje } \\
\text { mleka (kg) }\end{array}$ & $\begin{array}{l}\text { Prebavljive } \\
\text { beljakovine } \\
\text { za proizva- } \\
\text { janje mleka } \\
\text { (kg)** }\end{array}$ & $\begin{array}{l}\text { Škrob } \\
\text { za vzdr- } \\
\text { ževanje te- } \\
\text { lesne mase } \\
\text { (kg) }\end{array}$ & $\begin{array}{l}\text { Prebavljive } \\
\text { beljakovine } \\
\text { za vzdrže- } \\
\text { vanje telesne } \\
\text { mase (kg) }\end{array}$ & $\begin{array}{l}\text { Skupaj } \\
\text { skkobne } \\
\text { enote } \\
\text { (kg) }\end{array}$ & $\begin{array}{l}\text { Skupaj } \\
\text { prebavljive } \\
\text { beljakovine } \\
\text { (kg) }\end{array}$ \\
\hline $\begin{array}{l}\text { Dnevne } \\
\text { potrebe po } \\
\text { škrobu in } \\
\text { beljakovinah }\end{array}$ & 20 & 5,5 & 1,2 & 3,2 & 0,32 & 8,7 & 1,52 \\
\hline $\begin{array}{l}\text { Letne } \\
\text { potrebe po } \\
\text { škrobu in } \\
\text { beljakovinah }\end{array}$ & 6100 & 1677,5 & 366 & 976 & 97,6 & 2654 & 463,6 \\
\hline
\end{tabular}

Vira/Sources: Korošec, 1989; Podgoršek, Perpar, 2012

* Ob 4 \%-ni vsebnosti maščob ter z osnovo $275 \mathrm{~g}$ škrobnih enot na liter mleka, dnevno

** Ob 4 \%-ni vsebnosti maščob ter z osnovo $60 \mathrm{~g}$ prebavljivih beljakovin za liter mleka, dnevno

Dnevne potrebe krave molznice po hranilih so torej $8,7 \mathrm{~kg}$ čistega škroba (ŠE) ter $1,52 \mathrm{~kg}$ prebavljivih beljakovin (PB). Letne potrebe krave molznice za obdobje laktacije znašajo $2654 \mathrm{~kg}$ čistega škroba in 463,6 kg prebavljivih beljakovin. Največ škroba in beljakovin potrebujejo krave molznice za proizvodnjo mleka. Čistega škroba za proizvodnjo mleka je potrebno kar $42 \%$ več kot za vzdrževanje telesne mase. Pri prebavljivih beljakovinah so te vrednosti še višje, kar 73 \% beljakovin se porabi za proizvodnjo mleka. Kmetovalec mora ob tem upoštevati tudi, da izbrana krma ne vsebuje le čistega škroba in beljakovin, ampak še druga hranila ter ostale snovi (Korošec, 1989). Zato so lahko končne količine krme manjše. 
Preglednica 4: Odkupna cena pridelka na hektarju površine nekaterih krmnih rastlin v letu 2012 Table 4: Price of yields per hectare for some fodder crops in 2012

\begin{tabular}{|l|c|c|c|c|c|c|}
\hline & $\begin{array}{c}\text { Škrobne } \\
\text { enote } \\
(\mathrm{kg})\end{array}$ & $\begin{array}{c}\text { Prebavljive } \\
\text { beljakovine } \\
(\mathrm{kg})\end{array}$ & $\begin{array}{c}\text { Potrebna } \\
\text { dnevna količina } \\
\text { krme za } \\
\text { pridelavo 20 1 } \\
\text { mleka (kg) }\end{array}$ & $\begin{array}{c}\text { Hektarski } \\
\text { donos v } \\
\text { letu 2012 } \\
\text { (t/ha) }\end{array}$ & $\begin{array}{c}\text { Povprečna } \\
\text { cena 1 kg } \\
\text { krme v letu } \\
\text { 2012 (€) }\end{array}$ & $\begin{array}{c}\text { Odkupna } \\
\text { cena } \\
\text { pridelka na } \\
\text { hektarju } \\
\text { površine }(€)\end{array}$ \\
\hline $\begin{array}{l}\text { Srednje kakovostno seno } \\
\text { (različne travne mešanice; } \\
\text { dvakratna letna košnja) }\end{array}$ & 0,30 & 0,09 & 27,33 & 4,60 & $0,15^{*}$ & 690,00 \\
\hline $\begin{array}{l}\text { Zelo kakovostno seno } \\
\text { (različne travne mešanice; } \\
\text { trikratna letna košnja) }\end{array}$ & 0,40 & 0,10 & 20,50 & 5,50 & 0,10 & 572,72 \\
\hline Silažna koruzna krma & 0,19 & 0,04 & 44,32 & 39,40 & $0,065^{* *}$ & 2561,00 \\
\hline $\begin{array}{l}\text { Travna silaža (trava in } \\
\text { travne mešanice; trajni } \\
\text { travniki) }\end{array}$ & 0,17 & 0,04 & 49,70 & 12,80 & $0,06^{* * *}$ & 768,00 \\
\hline $\begin{array}{l}\text { Lucerna (pašna trava, } \\
\text { zelena krma) }\end{array}$ & 0,10 & 0,03 & 82,00 & 6,40 & $0,08^{* * * *}$ & 512,00 \\
\hline $\begin{array}{l}\text { Črna detelja (pašna trava, } \\
\text { zelena krma) }\end{array}$ & 0,11 & 0,03 & 78,10 & 5,60 & $0,08^{* * * *}$ & 448,00 \\
\hline $\begin{array}{l}\text { Inkarnatka (pašna trava, } \\
\text { zelena krma, le poleti; } \\
\text { pridelek v okviru DTM) }\end{array}$ & 0,11 & 0,02 & 75,93 & 5,60 & $0,08^{* * * *}$ & 448,00 \\
\hline Krmna žita - koruzno zrnje & 0,82 & 0,07 & 10,00 & 7,10 & 0,20 & 1420,00 \\
\hline Krmna žita-ječmen & 0,70 & 0,08 & 11,71 & 4,70 & 0,18 & 846,00 \\
\hline Krmna žita- pšenica & 0,75 & 0,10 & 10,93 & 5,50 & 0,20 & 1100,00 \\
\hline Krmna žita - proso & 0,67 & 0,08 & 12,24 & 1,60 & 0,42 & 667,68 \\
\hline Sirek (suha krma) & 0,09 & 0,07 & 91,11 & 4,30 & $\mathrm{NP}$ & $\mathrm{NP}$ \\
\hline
\end{tabular}

Viri/Sources: Korošec, 1989; Krznar, 2013; Indeksi cen in ..., 2013

* Cena je ocena na osnovi različnih virov (mdr. oglasov kmetovalcev)

** Cena je bila preračunana iz cene $65 €$ za $1000 \mathrm{~kg}$ težko silažno balo

*** Cena je bila preračunana iz cene $30 €$ za $500 \mathrm{~kg}$ težko silažno balo

**** Cena je bila preračunana iz cene $40 €$ za $500 \mathrm{~kg}$ težko silažno balo (krma s $66 \%$ suhe snovi)

NP ni podatkov o ceni

V prvem delu preglednice 4 podajamo izračune količin čistega škroba in prebavljivih beljakovin v posamezni krmni rastlini ter predvidene dnevne količine krme za zadostitev potreb krave molznice po hranilih. Največje količine čistega škroba pridelamo s krmnimi žiti, med 0,67 in $0,82 \mathrm{~kg}$ na $1 \mathrm{~kg}$ celotne mase pridelka, saj se v zrnu akumulira največja količina škroba glede na celotno rastlino. V travnati in koruzni silaži je ta količina nižja, saj ta vsebuje več sveže snovi. Vrednosti čistega škroba so podobne tistim, ki jih pridobimo z zeleno krmo metuljnic (lucerna, črna detelja, inkarnatka) (Korošec, 1989). Precej višje vrednosti čistega škroba od pričakovanih so pri različno kakovostnem senu travnih mešanic. Razlog je v večji akumulaciji škroba v bolj posušenem senu (Prepadnik, 
2012). Največ prebavljivih beljakovin vsebujejo posušeno seno ter krmna žita, med 0,07 in $0,10 \mathrm{~kg}$ na $1 \mathrm{~kg} \mathrm{krme}$. Metuljnice in travnata ter koruzna silaža vsebujejo nekoliko manj beljakovin, okoli $0,04 \mathrm{~kg}$ na $1 \mathrm{~kg}$ krme.

Krma iz samo ene krmne rastline se v živinski krmi ne pojavlja pogosto, saj kmetovalci sestavljajo krmo glede na količine hranilnih snovi (Korošec, 1989; Podgoršek, Perpar, 2012). Drugi razlog za uporabo pestre krme je v sami količini. Krava molznica je dnevno zmožna s krmo zaužiti med 15 in 20 kg suhe snovi, odvisno od pasme in možnosti laktacije (Orešnik, Lavrenčič, 2013). Iz preglednice 4 je razvidno, da bi bilo realno mogoče krmiti živino z eno vrsto krme le v primeru sena in krmnih žit. V ostalih primerih so količine krme zelo velike, zato je v takšnih primerih potrebno kombinirati z drugimi krmnimi rastlinami. Pri travni in koruzni silaži so vrednosti količine krme med 44 in 50 kg suhe snovi dnevno, pri metuljnicah med 75 in $82 \mathrm{~kg}$ suhe snovi. Še posebej visoke so vrednosti pri sirku, kar $91 \mathrm{~kg}$ suhe snovi.

$\mathrm{V}$ zadnjem delu preglednice 4 so prikazani hektarski donosi krmnih rastlin, povprečne odkupne cene $1 \mathrm{~kg}$ pridelka ter odkupna cena pridelka, pridelanega na hektarju površine. Največji hektarski donosi so tako pri silažni koruzi, za približno pol manjši ali več pri travni silaži, krmnih žitih (koruza v zrnju, pšenica) in lucerni. Ostale krmne rastline dosegajo nižje hektarske donose, še posebej proso (1,6 t/ha). Odkupne cene $1 \mathrm{~kg}$ krme so najvišje pri krmnem žitu, npr. za proso kar $0,42 €$ za kg; najnižje so za metuljnice ter silažo, npr. za koruzno silažo $0,065 €$ za kg. Če upoštevamo še hektarski donos, da dobimo odkupno ceno pridelka, vidimo opazne razlike med krmnimi rastlinami. Najvišje odkupne cene dosegajo koruzna silaža in krmna žita, najnižje pa krmne metuljnice in različno kakovostno seno.

Če želimo izbrati najprimernejšo krmno rastlino, je potrebno od prihodkov pridelka, pridelanega na hektarju površine, odšteti vse stroške pridelave. Pri izračunih stroškov so upoštevani vsi izdatki, oddaljenost parcele od kmetije, do odkupnega mesta, stroški setve, spravila, materiala, dela in drugih obveznih dajatev. V preglednici 5 so prikazani rezultati takšnih izračunov, ki smo jih povzeli po Kmetijskem inštitutu Slovenije (Kalkulacije v rastlinski ..., 2013). Najvišji stroški pridelave so pri koruzi za zrnje in silažo, najnižji pa pri krmnih žitih. Podatkov za izbrane metuljnice ni bilo mogoče pridobiti.

Preglednica 5: Stroški pridelave izbranih krmnih rastlin glede na povprečni hektarski donos v letu 2012

Table 5: The production costs of selected fodder crops according to the average yield per hectare in 2012

\begin{tabular}{|l|c|}
\hline Krmna rastlina & $\begin{array}{c}\text { Stroški pridelave v letu 2012 glede na } \\
\text { povprečen hektarski donos }(\mathbf{E} / \mathbf{h a})\end{array}$ \\
\hline Pšenica & 983,42 \\
\hline Ječmen za prodajo & 890,08 \\
\hline Koruza za zrnje & 1598,04 \\
\hline Silažna koruza & 1776,24 \\
\hline Ječmen za domačo krmo & 878,78 \\
\hline Travna silaža & 1278,96 \\
\hline Seno (trikosni travnik s 7,9 t/ha) & 1398,63 \\
\hline
\end{tabular}

Vir/Source: Kalkulacije v rastlinski ..., 2013 
Rezultati analize ekonomike pridelovanja rastlin kažejo, da se z vidika kmetovalca finančno bolj splača pridelovanje sena, krmnih žit in silažne koruze kot pridelovanje metuljnic. Te so sicer odpornejše na kmetijsko sušo, kot smo že ugotovili v prvem delu analize. Kmetovalec lahko z njimi zagotovi zadostne količine krme za dnevne potrebe krave molznice ali lahko ob prodaji krme zasluži. Po drugi strani so stroški pridelovanja silažne koruze, travne silaže in sena precej visoki v primerjavi s pridelovanjem krmnih žit. S prodajo sena trikosnega travnika ima kmetovalec vsaj enkratno izgubo, saj so stroški pridelave precej visoki.

\section{SKLEP}

V prvem delu analize smo dokazali, da je glede odpornosti na sušo lucerna najprimernejša krmna rastlina kot nadomestek silažni koruzi. Lucerna je tako pri analizi podatkov popisa škode zaradi suše kot pri NDVI dosegla nižje vrednosti in bila manj prizadeta zaradi suše kot koruza za silažo. Tudi ostale preučevane krmne rastline dosegajo vrednosti NDVI in stopnje poškodovanosti po popisu škode, ki dokazujejo, da so ob suši manj prizadete in odpornejše nanjo kot silažna koruza. $Z$ vidika ekonomike pridelovanja ugotavljamo, da metuljnice kot samostojna krma niso primerne, zato bi jih bilo potrebno kombinirati z drugimi rastlinami.

Na podlagi več kriterijev so z ekonomskega vidika najprimernejše nadomestilo za silažno koruzo različna sena travnih mešanic ter krmna žita. Pridelovanje travnih mešanic je tudi stroškovno zahtevno, kmetovalec bi bil z njihovo prodajo celo v izgubi. Veliko bolj ekonomsko donosna so nekatera krmna žita (pšenica, ječmen). Vendar so to le teoretični predlogi nadomeščanja rastlin v strukturi krme, ki se lahko močno razlikujejo od dejanskega načina krmljenja živali. Zato bi bile potrebne še dodatne analize, ki bi tudi v praksi potrjevale ustreznost izbranih krmnih rastlin kot nadomestilo za silažno koruzo. S kompleksno analizo smo pokazali, da pri kmetovalcih, ki sami pridelujejo krmo, izbira krme samo z ekonomskega vidika ni najbolj ustrezna. V prihodnosti bo tako zaradi vse ekstremnejših vremenskih razmer potrebno upoštevati odpornost rastlin v različnih situacijah ter tudi druge rastne značilnosti, kar je bilo do sedaj bolj drugotnega pomena.

$\mathrm{V}$ prihodnjih analizah bi bilo potrebno ugotavljanje primernosti določenih krmnih rastlin kot nadomestilo silažni koruzi razširiti na daljše časovno obdobje. Žal zgolj eno vegetacijsko obdobje ne omogoča splošno veljavnih ugotovitev, saj se sušni dogodki med seboj zelo razlikujejo. Vsaka suša je posebna in zato tudi različno vpliva na fenološki razvoj rastlin. Podobno velja tudi za preučevanje ekonomike pridelovanja. Z enim vegetacijskim obdobjem ne zajamemo razlik v spremembah cen, količin letnega pridelka in povpraševanja. Tudi ti vidiki so zelo pomembni, saj prav tako vplivajo na izbiro krmne rastline.

Dodatno bi bilo potrebno izbrati tudi večje preučevano območje, ker bi tako prišli do ključnih ukrepov za posamezno območje. Ključni dejavnik pri tovrstnih raziskavah so tudi podatki o poljščinah. Na primeru šifranta kulturnih rastlin posamezne enote GERK vidimo, da zaradi metodologije vpisa ne moremo opravljati analize za točno določeno poljščino. Na večjem preučevanem območju bi tako pridobili širši nabor 
potencialnih nadomestnih krmnih rastlin, kar bi verjetno dalo konkretnejše rezultate in možnost primerjave.

Potrebno bi bilo pridobiti tudi novejše podatke o količini škrobnih enot in prebavljivih beljakovin v krmi ter dnevnih potreb hranil pri živalih, ali uporabiti podatke o energijski vrednosti krme. Poleg tega bi bilo potrebno uporabiti kakovostnejše satelitske posnetke, saj smo pri tej analizi uporabili posnetek z $22 \%$ manjkajočih podatkov, kar zelo zmanjšuje natančnost rezultatov in tudi splošnih ugotovitev.

\section{Viri in literatura}

Adaptation strategies. 2014. European climate adaptation platform. URL: http://climate-adapt.eea.europa.eu/web/guest/adaptation-strategies (Citirano 26. 2. 2015).

Bernik, R., 1998. Poljedelstvo v preteklosti. Ljubljana, Biotehniška fakulteta, Oddelek za agronomijo, $42 \mathrm{str}$.

Brilly, M., Šraj, M., 2005. Osnove hidrologije. Ljubljana, Fakulteta za gradbeništvo in geodezijo, 309 str.

Cizej, D., 1991. Govedoreja: priročnik o zreji, krmljenju in gospodarnosti goved na kmetijah. Maribor, Založba Obzorja, 247 str.

Geografski terminološki slovar. 2005. Ljubljana, Založba ZRC, 451 str.

Čergan, Z., 2008. Koruzna rastlina in rastne zahteve. V: Čergan, Z. (ur.). Koruza. Ljubljana, Kmečki glas, str. 22-40.

Družinski člani na družinskih kmetijah po starostnih skupinah, po občinah, Slovenija, 2000 in 2010. SI-STAT podatkovni portal. Statistični urad Republike Slovenije. 2015. URL: http://pxweb.stat.si/pxweb/Dialog/varval.asp?ma=15P4209S\&ti=\&path=../Database/ Kmetijstvo_2010/05_delovna_sila/03_15P42_obcine/\&lang=2 (Citirano 23. 11. 2015).

Grah, M., 2012. Suša sredi padavinskega otoka Evrope. Delo, Panorama. URL: http:// www.delo.si/druzba/panorama/susa-sredi-padavinskega-otoka-evrope.html (Citirano 29. 3. 2013).

Indeksi cen in cene kmetijskih pridelkov pri pridelovalcih, kmetijski pridelek, leto in meritve, Slovenija, leto. 2013. SI-STAT podatkovni portal. Statistični urad Republike Slovenije. URL: http://pxweb.stat.si/pxweb/Dialog/varval. asp?ma $=0410802 \mathrm{~S} \& \mathrm{ti}=\& \mathrm{path}=. . /$ Database/Ekonomsko/04_cene/04108_IC$\mathrm{KPP} / \&$ lang=2 (Citirano 7. 12. 2014).

Kalkulacije v rastlinski pridelavi 2012. 2013. Kmetijski inštitut Slovenije. URL: http:// www.kis.si/datoteke/file/kis/SLO/EKON/RASTLINSKA_2012.xls (Citirano 7. 12. 2014).

Kmetijska gospodarstva po rabi vseh in kmetijskih zemljišč v uporabi, po občinah, Slovenija 2000 in 2010. 2013. Statistični urad Republike Slovenije. SI-STAT podatkovni portal. URL: http:/pxweb.stat.si/pxweb/Dialog/varval. asp?ma $=15$ P2201 S\&ti=\&path $=$. /Database/Kmetijstvo_2010/03_zemljisca_raba/03_15P22_obcine/\&lang=2 (Citirano 16. 12. 2014).

Korošec, J., 1989. Pridelovanje krme. Ljubljana, Kmečki glas, 181 str. 
Krepitev pripravljenosti Evrope na naravne nesreče in nesreče, ki jih povzroči človek. 2013. Evropska komisija. URL: http://europa.eu/rapid/press-release_IP-13-329 sl.htm (Citirano 26. 2. 2015).

Krznar, J., 2013. Rastlinska pridelava, Slovenija, 2012 - končni podatki. Statistični urad Republike Slovenije. URL: http://www.stat.si/novica_prikazi.aspx?id=5400 (Citirano 8. 12. 2014).

NASA Landsat Program, Landsat 7 ETM+, scena LE71900282012191ASN00, L1T, Sioux Falls, 9/07/2012. URL: http://glovis.usgs.gov (Citirano 1. 5. 2013).

Ocena škode na kmetijskih kulturah. 2013. Komisija za ocenjevanje škode. Ministrstvo za obrambo, Uprava RS za zaščito in reševanje (osebni vir, 21. 3. 2013). Ljubljana.

Orešnik, A., Lavrenčič, A., 2013. Krave molznice: prehrana, zdravstveno varstvo in reprodukcija. Ljubljana, Kmečki glas, 184 str.

Oštir, K., 2006. Daljinsko zaznavanje. Ljubljana, Založba ZRC, 241 str.

Podatki o vrsti kmetijskih rastlin na GERK-ih v občinah Spodnje Savinjske doline. 2013. Agencija za kmetijske trge in razvoj podeželja (osebni vir, 15. 3. 2013). Ljubljana.

Podgoršek, P., Perpar, T., 2012. Mlečnost kontroliranih krav. Govedorejec, 20, str. 15-16. URL: http://www.kmetijskizavod-celje.si/images/upload/2013/738_GOVEDOREJEC_2012_.pdf (Citirano 22.11.2015).

Prepadnik, H., 2012. Siliranje koruze, ki jo je prizadela suša. Kmetijsko gozdarska zbornica Slovenije (osebni vir, 25. 2. 2013). Žalec.

Stevenson, M., 2012. Using ArcGIS for landcover classification. Core GIS. URL: http:// www.waurisa.org/conferences/2012/presentations/11\%20Matt $\% 20$ Stevenson $\% 20$ Using\%20ArcGIS\%20for\%20Landcover\%20Classification $\% 20$ from $\% 20$ Landsat\%20Imagery.pdf (Citirano 1. 6. 2013).

Tehnološka priporočila za zmanjšanje občutljivosti kmetijske pridelave na sušo. 2008 . Hardi, Z. (ur.). Ljubljana, Ministrstvo za kmetijstvo, gozdarstvo in prehrano, 43 str. URL: http://www.kis.si/datoteke/File/kis/SLO/Publikacije/drugo/Tehnoloska_priporocila_za_zmanjsanje_obcutljivosti_na_suso.pdf(Citirano 12.9. 2014).

\section{MULTICRITERIA EVALUATION EXPERIMENT OF THE ALTERNATI- VE FODDER CROPS USE IN THE RESEARCH OF THE LOWER SAVI- NJA VALLEY}

\section{Summary}

In the first part of the analysis (plant resistance), we have proven that alfalfa is the best fodder crop as a substitute for silage maize. Comparing the results of the census data loss due to the drought in 2012 and NDVI values, the alfalfa scored much better (higher NDVI) than the silage maize. The other analysed fodder crops have similar values, demonstrating that they are less prone to damages by drought and more resistant than silage maize. Regarding the economics of the production, the fodder legumes are considerably less suitable, so they had to be combined with other plants. According to the several economic criteria, the most appropriate compensation to silage maize is a 
various mixture of grass hay and feed grains. However, growing grass mixtures is very costly and does not compensate all the investments. Much more economically viable are some feed grains (wheat, barley). Additional analysis is suggested which would confirm the suitability of the selected alternative plants as a replacement for silage maize in practice. In the somewhat complex analysis, we have proven that choice of the fodder crop cannot be made only from the economic point of view. Since more extreme weather conditions are expected in the future, farmers will need to consider also plant resistance to various weather situations and other growth characteristics, which had been until now of secondary importance.

Further analyses of the suitability of certain fodder crops as substitute to silage maize would have to be extended over a longer period. Drought events considerably differ from each other and have therefore quite different effects on phenological development of the plants. One growing season simply does not take into account the differences in price changes, annual production volumes and market demands. These aspects are very important, since the periodic fluctuations influence the farmer's choice of fodder crops.

At the same time, it would also be necessary to extend the studied area, as this would bring the differences between the inner parts of study area and therefore specific key actions in each area could be proposed. The specific data proved to be a key factor in the study, since in the case of the graphic parcel crop code of agricultural land (in Slovenian GERK), an analysis entry cannot be made for each specific crop plant. With broader study area we would also gain a wider range of different potential alternative fodder crops.

It would also be necessary to obtain the most recent data on the starch unit quantities, available digestible proteins in feed and animal's daily nutrient requirements or use the data of the energy value of feed. Finally, the use of satellite imagery of the highest quality would greatly improve the accuracy of the results and general observations. The results of the analysis based on the images with $22 \%$ of missing data proved to be very problematic.

(Translated by the authors) 